\title{
Automobile Trips to School and Safety Perspectives of Unplanned Lokoja Metropolis in North Central Nigeria \\ * Dr. Adetunji Musilimu Adeyinka
}

Faculty of Social Sciences, Federal University Lokoja, Kogi State, Nigeria

E mail: musilimuadetunji@yahoo.com

\section{ART I CLE INFO:}

Article history:

Received 23 March 2019

Accepted 3 August 2019

Available online 1 September 2019

Keywords:

Urban:

Transportation;

Location:

Safety;

Planning.

This work is licensed under a Creative Commons Attribution

NonCommercial - NoDerivs 4.0. "CC-BY-NC-ND"

\section{(c) $(1) \odot$}

This article is published with Open Access at www.ijcua.com

\section{A B S T R A C T}

Many studies on transport research did not consider the consequences of high reliance on an automobile trip to schools which frequently resulted in road traffic crashes, traffic delay, and late arrival to school, injuries and sometimes death of victims especially students. As a result, this research examines the consequences of automobile trip to school among secondary school students in the Lokoja metropolis. It aims to investigate the safety of the use of automobile in an unplanned city like Lokoja, with the specific objectives of ascertaining the number of pupils who embark on different automobile trips; the safety measures, and the casualty cases. Three hundred students were selected for questionnaire administration across six selected secondary schools in the city. Data on students' road traffic crashes were obtained from archives. Descriptive and inferential statistics were employed for analyses. Findings reveal that more than $70 \%$ of students rely on automobile to travel to schools. Car trips to schools were more among students of private secondary schools. Students in private secondary schools rely more on the use of a school bus. It was also discovered that students were involved more in traffic crashes along major roads. The study concludes on the use of school bus by students instead of relying on private cars.

\section{JOURNAL OF CONTEMPORARY URBAN AFFAIRS (2020), 4(1), 61-70.} https://doi.org/10.25034/ijcua.2020.v4n1-6

www.ijcua.com

Copyright ( 2019 Journal of Contemporary Urban Affairs. All rights reserved.

\section{Introduction}

Within the last two decades the number of registered vehicles in Nigeria has increased tremendously from 349, 417 in 1999 to 13, 214, 019 in the year 2017. Motor vehicles increased from 222, 507 to $7,928,132$ for the same period, while motorcycles increased from 126,910 to $5,285,887$ (Federal Road Safety Corps 2017). According to reports in the National Bureau of Statistics (2017), approximately $4,656,725$ vehicles are owned by individuals for their day to day transaction, while $6,749,461$ vehicles are registered as public transport services for both passengers and freight transport services in the country. The data suggests that the total number of Nigeria's vehicle per person is 0.06 .

This can be interpreted as very low compared to what is obtainable in some of the developed countries of the world where more than 0.70 vehicles are accessible for every person in Finland,

\section{*Corresponding Author:}

Faculty of Social Sciences, Federal University Lokoja, Kogi State, Nigeria

Email address: musilimuadeyinka@yahoo.com 
Italy, the USA, Austria to mention but a few (World Health, 2015). Incessant increase in the importation of fairly used vehicles in some developing countries such as Nigeria to meet their travel needs such as a trip to work, journey to schools, shopping and recreational activities has created serious bottlenecks for people because of inadequate road networks to accommodate vehicular movement (Ogunsanya, 2004). High automobile travel demand creates challenges that include traffic delay, road traffic crashes, fatigue and emission of toxic substances into the atmosphere that are harmful to human health (Kopnina \& Williams, 2012).

Until recently, research on children demands for automobile trip to schools was very scanty in the literature compared to work or health care trips. This apparent gap in the field of transport research is unwarranted for any country striving to achieve a sustainable transport policy in the $21^{\text {st }}$ Century. Studies in different parts of the world have shown that trip to school is one of the most important trip generations in any urban centre in the world. This is because it involves the children and their parents that accompany their wards to school (Baker et al., 2005; Department for Transport, 2014). Detailed information on the journey to school is highly essential because pupils can be trained to travel on their own and also because school trips generate problems such as traffic crashes, emission of toxic substances and fatigue (Goeverden \& Boer, 2013). Studies have also shown that car congestion around schools during the peak times of arrival and departure creates a dangerous environment for children that walk, cycle or use public transport service to and from schools (Collins \& Kearns, 2001) as cited in Badri (2013). Similarly, traffic congestion along routes connecting schools create delay and late arrival to schools (Timperio et al., 2006) as cited in Badri (2013).

Furthermore, studies have shown that an increase in average distance from home to school in recent decades has resulted in high reliance on motorised modes of transportation such as car, and public transport services of all forms such as tricycle, motorcycle, taxi, bus and mass transit (Easton \& Ferrari, 2015). The use of automobile, particularly private car, is often associated with air pollution, carbon dioxide emission, traffic congestion, road traffic crashes and other environmental health challenges (Kopnina \& Williams, 2012). Short distance trips to school will promote walking and cycling and this will enhance sustainable transport to school (Goeverden \& Boer, 2013; Kim, 2014). In an assessment of journey to school in the U.S, Centres for Disease Control and Prevention (2012) reported that children do not get adequate physical activities and this contributes to their health problems. It, therefore, recommended an average of 60 minutes of physical activity per day for each student. In another case, an assessment of mode choice to schools in some of the developed countries, the socio-economic characteristics of the parents such as gender, employment status and level of educational qualifications determined the mode choice of their children to school. Women were more involved in escorting their wards to school (Kim, 2014). Studies on the mode choice to school in the developing world particularly in Nigeria emphasised that the location of schools relative to the residence of the students are the major determinants of mode choice (Ipingbemi \& Aiworo, 2013; Olawole, 2016). Some of these studies did not consider the health implications of high demand for automobile trip to school. These health implications include children traffic crashes and congestion that have resulted in public concern in some major and emerging cities in the developing world, Nigeria inclusive. According to the Federal Road Safety Corps (2017), the percentage of children injured in road traffic crashes on roads in Nigeria is $6 \%$, while the percentage of children killed in road traffic crashes is $7 \%$ (Federal Road Safety Corps 2017). In the same report, $39.8 \%$ of private vehicles were involved in road traffic crashes, $58.9 \%$ were commercial vehicles, while only $1.3 \%$ of the vehicles involved in the crashes were governmentowned (Federal Road Safety Corps 2017). It is interesting to note that many of these vehicles were conveying children to school (Badri, 2013). It is on this note that this study seeks to examine the mode choice of transportation of children to school and the implications of the high demand for automobile trips to school in the emerging city of Lokoja. This will give an avenue to propose a sustainable transport policy for school trips in the emerging city of Lokoja in north-central Nigeria.

\section{Study Area}

Lokoja metropolis is the study area. The city is located on latitude $7045^{\prime} 27.56^{\prime \prime}-7051^{\prime} 04.34^{\prime \prime} \mathrm{N}$ of the Equator and longitude 6041' 55.64" - 6045' 36.58" E of the Prime Meridian by the confluence of Rivers Niger and Benue (see figure 1), with a total land coverage of about $63.82 \mathrm{sq}$. km. (Adeoye, 2012). Lokoja built-up area comprises seven localities such as Lokoja Core Area, Adankolo, Lokongoma, Felele, Zango Daji, Army Barracks and Ganaja Village (National Population, 2007). These smaller localities which were formally separated from one another now merged to become larger Lokoja which constitute a major city in Kogi State (Olawepo, 2009). Shortly after Lokoja became the 
capital of Kogi State in 1991, the city witnessed rapid development as a result of the influx of people from neighbouring towns and villages.

Like many other cities in Nigeria, three types of road networks are found in the Lokoja metropolis. These include Trunk A- Federal Roads (highways), Trunk B- State Roads, and Trunk C- Local Government Roads. The Trunk A Roads comprise the federal highways that connect Lokoja to other towns and states of the federation. The Trunk BState Roads are the intra urban road networks. Many of these roads are poorly designed with nonpedestrian walkways. This has discouraged many pedestrians, particularly children to walk to and from school because of heavy traffic in the city. Many Trunk B roads are narrow, poorly maintained and connect few residential areas., many public transport services such as tricycles, taxis and mass transits are forced to use the federal highways in the city (Adeyinka, 2017). This has led to incessant road traffic congestions and traffic crashes within the metropolis. The last categories of the urban route in Lokoja metropolis are Local Government Roads that link low density residential parts of the city. Many of these roads are earth surfaced with poor transport facilities. Some of the children that live on the outskirts of Lokoja have less access to public transport services to the school.

Studies have also shown that the pattern of distribution of secondary schools in Lokoja is not evenly distributed (Adetunji \& Aloba, 2018). Virtually all public secondary schools in the city are located in High and Medium density areas of Lokoja. The inability of the government to provide educational facilities for the fast growing population of Lokoja has led to the proliferation of substandard secondary schools at the outskirts of the city. The preference for quality education has forced many parents to allow their wards to cross the city landscape, travelling long distances in order to access educational facilities located outside their localities (Adetunji \& Aloba, 2018). Many of these children rely on automobile to and from school.

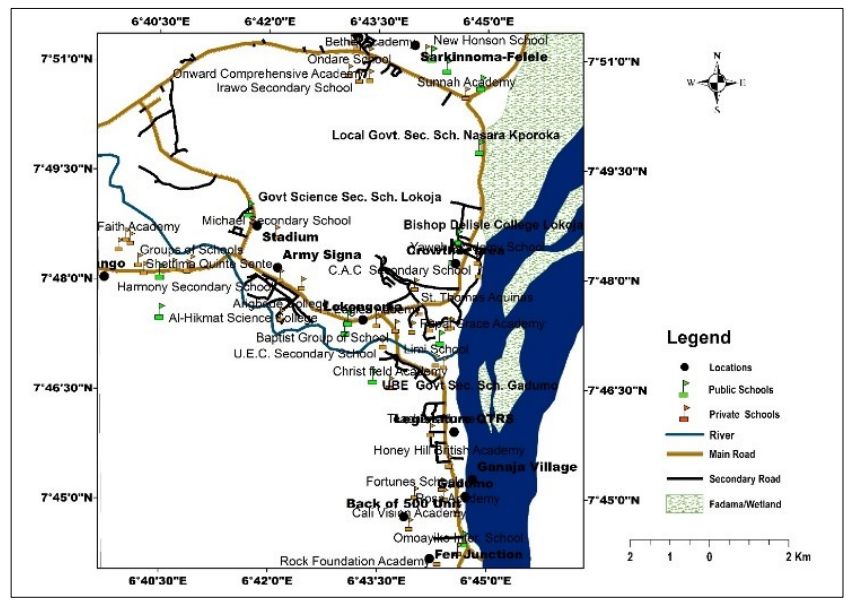

Figure 1. Distribution of Schools and Road Networks in Lokoja

\section{Adapted From: (Adetunji \& Aloba, 2018) 3. Materials and Methods}

Primary and secondary data were utilised for this study. Three sets of primary data were required for the study. The first category of data was based on socio-economic characteristics of secondary school children and their travel patterns such as mode choice of transportation, distance travelled and type of school attended. The second set of data focusing on parents' decisions on school attended by their wards and the number of children attending school in their family. The last group of data was based on children traffic crashes. Three public and private secondary schools with students' enrolment of more than 1000 population were purposively selected for the study. A structured questionnaire that was divided into two sections (parent decision on school choice for their wards and children mode preference to school) was designed to elicit information on mode trips to school. In each of the schools selected, an average of 40 children/students was selected using a table of random numbers across the junior and senior secondary schools in the city. The administration of the questionnaire to the students was done with the assistance of the principals of the selected schools. The questionnaires were given to the students and were taken home to be completed and returned the next day. Data on children (students) road traffic crashes were obtained from the archive of the Federal Medical Centre (2017) in Lokoja metropolis. Descriptive and inferential statistics were employed to analyse the data.

\section{Results and Discussion}

The principal mode of transport to secondary schools in Lokoja is by foot particularly when a short distance is involved. Table 1 reveals that $29.9 \%$ of secondary school students walk to schools in the city. This is at variance with the study carried out in Mission Hill School by Kim (2014), where 15\% of children engaged in walking to school (Kim, 2014). The use of private cars for school trip was ranked second (23.7\%) of the modal split in Lokoja. Approximately $16.6 \%$ and $17.1 \%$ of the sampled students rely on tricycle and motorcycle for trip to schools respectively. The result of this analysis reveals that more than $70 \%$ of the sampled students rely on automobile for their journey to school. The use of school bus for school trip is ranked lowest (12.8\%) among the children/students in Lokoja metropolis. This is contrary to the findings in a study of mode choice of transportation to schools in Abu Dhabi, the capital of the United Arab Emirate. In the findings, Badri (2013) reported that $45 \%$ of children travel to school by car, while $38.1 \%$ rely on school buses. However, the use of school bus for the journey to 
school in some of the advanced countries has been considered to be safer than the use of private cars to school (The Car Crash Detective, 2018).

Table 1: Mode of choice to secondary schools in Lokoja

\begin{tabular}{|ll|r|r|r|r|}
\hline & Frequency & Percent & Valid Percent & $\begin{array}{c}\text { Cumulative } \\
\text { Percent }\end{array}$ \\
\hline & Walk & 63 & 23.1 & 29.9 & 29.9 \\
& School bus & 27 & 9.9 & 12.8 & 42.7 \\
Valid & Tricycle & 35 & 12.8 & 16.6 & 59.2 \\
& Motor cycle & 36 & 13.2 & 17.1 & 76.3 \\
& Car & 50 & 18.3 & 23.7 & 100.0 \\
& Total & 211 & 77.3 & 100.0 & \\
Missing & System & 62 & 22.7 & & \\
Total & & 273 & 100.0 & & \\
\hline
\end{tabular}

The mode choice of transportation of children to school varies according to the type of school attended. Private secondary school children rely more on car trip to school compared to public secondary school children. Table 2 reveal that 32 $\%$ of private secondary school children depend on car trip to school while $16 \%$ of public school children rely on car trip. Further analysis shows that more than $30 \%$ of public secondary school children walk to school in contrast to $27.7 \%$ of private secondary school children. Similarly, the use of school bus for school trip is more pronounced among the children of private secondary schools (15\%) in comparison with public secondary school children (10.3\%).

Table 2: Mode Choice of Transportation to Different Type of School in Lokoja

\begin{tabular}{|c|c|c|c|c|c|c|}
\hline \multirow[t]{2}{*}{ Mode Choice } & & \multicolumn{4}{|c|}{$\begin{array}{c}\text { Type of school attended by } \\
\text { your children }\end{array}$} & \multirow[t]{2}{*}{ Total } \\
\hline & & \multicolumn{2}{|c|}{$\begin{array}{c}\text { Private } \\
\text { secondary } \\
\text { school }\end{array}$} & \multicolumn{2}{|c|}{$\begin{array}{c}\text { Public } \\
\text { secondary } \\
\text { school }\end{array}$} & \\
\hline \multirow{6}{*}{$\begin{array}{l}\text { Mode of choice to } \\
\text { school }\end{array}$} & & No & $\%$ & No & $\%$ & \\
\hline & Walk & 28 & 27.7 & 35 & 32.7 & 63 \\
\hline & School bus & 15 & 14.9 & 11 & 10.3 & 26 \\
\hline & Tricycle & 17 & 16.8 & 18 & 16.8 & 35 \\
\hline & Motor cycle & 9 & 8.9 & 26 & 24.3 & 35 \\
\hline & Car & 32 & 31.7 & 17 & 15.9 & 49 \\
\hline Total & & 101 & 100.0 & 107 & 100.0 & 208 \\
\hline
\end{tabular}

The decisions of parents to allow their ward to walk to school varies with: (1) No. of students attending school in the family, $F=8.985,<P .00$; (2)Distance of Residence to School, F=7.376 <P.01;(3) Route connected to the location of the school attended by the student, $F=8 . .699<$ P.00; (4)Type of School attended by students, $F=1.960<P .17$ (see Table 3 ). In many communities in Africa where many families are polygamous, there is a tendency for children to walk to school particularly where many students are of school age. Also, children whose schools are located in their neighbourhoods may likely walk to school in contrast to children with schools outside their localities. The route leading to the location of a school attended by the children also determines to a large extent whether the children walk or rely on automobile to school. The provision and availability of pedestrian walkways and location of schools away from heavy traffic may encourage parents to allow their wards to walk to schools rather than rely on automobile for trip to schools. 
Table 3: Variables that Determine whether Children Walk to School in Lokoja

\begin{tabular}{|c|c|c|c|c|c|c|}
\hline \multicolumn{7}{|c|}{ ANOVA } \\
\hline & & Sum of Squares & Df & Mean Square & $\mathrm{F}$ & Sig. \\
\hline \multirow{3}{*}{$\begin{array}{l}\text { No of students attending } \\
\text { school in the family }\end{array}$} & Between Groups & 4.410 & 1 & 4.410 & 8.985 & .003 \\
\hline & Within Groups & 48.100 & 98 & .491 & & \\
\hline & Total & 52.510 & 99 & & & \\
\hline \multirow{3}{*}{$\begin{array}{l}\text { Type of school attended } \\
\text { by your children }\end{array}$} & Between Groups & .490 & 1 & .490 & 1.960 & .165 \\
\hline & Within Groups & 24.500 & 98 & .250 & & \\
\hline & Total & 24.990 & 99 & & & \\
\hline \multirow{3}{*}{$\begin{array}{l}\text { Distance of your residence } \\
\text { to school }\end{array}$} & Between Groups & 4.255 & 1 & 4.255 & 7.376 & .008 \\
\hline & Within Groups & 54.234 & 94 & .577 & & \\
\hline & Total & 58.490 & 95 & & & \\
\hline Route connected to the & Between Groups & 5.813 & 1 & 5.813 & 8.699 & .004 \\
\hline location of the school & Within Groups & 62.145 & 93 & .668 & & \\
\hline \multirow[t]{2}{*}{ attended by your children } & Total & 67.958 & 94 & & & \\
\hline & Between Groups & .423 & 1 & .423 & 1.687 & .197 \\
\hline \multirow[t]{2}{*}{ Sex of the student } & Within Groups & 24.538 & 98 & .250 & & \\
\hline & Total & 24.960 & 99 & & & \\
\hline
\end{tabular}

It is pertinent to note that many parents prefer their wards to travel to school by automobile as a result of the consideration of many factors. For instance, Table 4 indicates that $42.5 \%$ of parents considered convenience as the most priority for their wards to travel using automobiles. More than $50 \%$ of parents considered safety as an important factor for allowing their wards to travel by automobile to school because many secondary schools in Lokoja are located on major roads where traffic is heavy during peak periods.

Table 4: Parent Preference on Automobile Trips to School

\begin{tabular}{|ll|r|r|r|r|}
\hline & Frequency & Percent & Valid Percent & Cumulative Percent \\
\hline \multirow{4}{*}{ Valid } & Convenience & 99 & 36.3 & 42.5 & 42.5 \\
& Safety & 120 & 44.0 & 51.5 & 94.0 \\
& Weather condition & 14 & 5.1 & 6.0 & 100.0 \\
& Total & 233 & 85.3 & 100.0 & \\
Missing & System & 40 & 14.7 & & \\
Total & & 273 & 100.0 & & \\
\hline
\end{tabular}

Studies have shown that high demand for automobile trip to school has serious implications on student's health in terms of air pollution around the school premises, traffic congestion and road traffic crashes that result in injuries and deaths of children who are the leaders of tomorrow (Goeverden \& Boer, 2013; Kim, 2014). In the last twelve months, thousands of children who are of school age have been involved in road traffic crashes in Nigeria. Table 5 indicates that 1765 children were injured in road traffic crashes in 2017 in Nigeria. Kaduna State has the highest number
(225) of children injured in road traffic crashes. This is closely followed by Kano State with a total number of 142 children. Akwa lbom and the Cross River States recorded the lowest number of children injured in road traffic crashes with 2 and 5 respectively. Kaduna State recorded the highest number of children that died in road traffic crashes. Bauchi State was ranked second in terms of children who lost their lives in road traffic crashes in 2017 in Nigeria. 
Table 5: Number of Children involved in Road Traffic Crashes on State Basis in 2017

\begin{tabular}{|l|l|l|}
\hline State & $\begin{array}{l}\text { Number of } \\
\text { Children } \\
\text { Injured on } \\
\text { Road Traffic } \\
\text { Crashes }\end{array}$ & $\begin{array}{l}\text { Children } \\
\text { Killed }\end{array}$ \\
\hline Abia & 11 & 0 \\
\hline Adamawa & 12 & 2 \\
\hline Akwa lbom & 2 & 4 \\
\hline Anambra & 16 & 8 \\
\hline Bauchi & 128 & 23 \\
\hline Bayelsa & 4 & 4 \\
\hline Benue & 49 & 12 \\
\hline Borno & 6 & 4 \\
\hline Cross River & 5 & 0 \\
\hline Delta & 15 & 7 \\
\hline Ebonyi & 21 & 11 \\
\hline Edo & 56 & 19 \\
\hline Ekiti & 11 & 1 \\
\hline Envgu & 61 & 6 \\
\hline
\end{tabular}

\begin{tabular}{|l|l|l|}
\hline FCT & 102 & 9 \\
\hline Gombe & 46 & 6 \\
\hline Imo & 19 & 3 \\
\hline Jigawa & 66 & 12 \\
\hline Kaduna & 225 & 53 \\
\hline Kano & 142 & 18 \\
\hline Katsina & 114 & 11 \\
\hline Kebbi & 19 & 2 \\
\hline Kogi & 62 & 18 \\
\hline Kwara & 34 & 10 \\
\hline Lagos & 22 & 5 \\
\hline Nasarawa & 106 & 10 \\
\hline Niger & 82 & 20 \\
\hline Ogun & 67 & 7 \\
\hline Ondo & 52 & 20 \\
\hline Osun & 88 & 15 \\
\hline Oyo & 84 & 8 \\
\hline Plateau & 48 & 8 \\
\hline Total & 1765 & \\
\hline
\end{tabular}

Source: Federal Road Safety Corps (2017)

The situation in which children are involved in road traffic crashes in the Lokoja metropolis is not at variance with what occurs in other states of Nigeria. For instance, Table 6 reveals that 136 children were involved in road traffic crashes in Lokoja in 2011 . As high as 28 children were involved in road traffic crashes in December 2011. This period coincided with the festive period when the flow of vehicular traffic is heaviest in the city. The number of children involved in road traffic crashes reduced from 136 in 2011 to 87 in 2012 . Table 6 indicates that 14 children were involved in road traffic crashes in January, August and December 2012 respectively.

Table 6: Children Traffic Crashes for 2011 and 2012

\begin{tabular}{|l|l|l|}
\hline MONTHS & $\mathbf{2 0 1 1}$ & $\mathbf{2 0 1 2}$ \\
\hline JANUARY & 7 & 14 \\
\hline FEBRUARY & 3 & 7 \\
\hline MARCH & 12 & 4 \\
\hline APRIL & 7 & 5 \\
\hline MAY & 6 & 01 \\
\hline JUNE & 13 & 8 \\
\hline JULY & 16 & 9 \\
\hline AUGUST & 22 & 14 \\
\hline SEPTEMBER & 1 & 6 \\
\hline OCTOBER & 9 & 1 \\
\hline NOVEMBER & 12 & 4 \\
\hline DECEMBER & 28 & 14 \\
\hline & 136 & 87 \\
\hline TOTAL & & \\
\hline
\end{tabular}

Source: Extracted from the Archive of FRSC, Lokoja Kogi State, 2012

At a more disaggregate level, the number of children of school age involved in road traffic crashes are more pronounced along LokojaKabba Junction route and Lokoja- GanajaAnyigba road(See Table 7). 
Table 7: Children Involved in Road Traffic Crashes across Different Routes Segments in Lokoja Metropolis 2011-212

\begin{tabular}{|c|c|c|c|c|c|c|c|c|}
\hline \multirow[t]{2}{*}{ LOCATION } & \multicolumn{6}{|c|}{ ROAD CRASHES ALONG DIFFERENT ROUTES } & \multirow[b]{2}{*}{$\begin{array}{l}\text { No.of } \\
\text { Crashes }\end{array}$} & \multirow[b]{2}{*}{ Months } \\
\hline & \multicolumn{2}{|c|}{$\begin{array}{l}\text { Lokoja-Koton- } \\
\text { Karffe-Abuja }\end{array}$} & \multicolumn{2}{|c|}{$\begin{array}{l}\text { Lokoja- } \\
\text { Ajaokuta }\end{array}$} & \multicolumn{2}{|c|}{$\begin{array}{l}\text { Lokoja-Zariagi } \\
\text { - Okene }\end{array}$} & & \\
\hline Felele & 2 & - & - & - & - & 1 & 3 & January \\
\hline Koton-Karffe & 3 & 2 & - & - & - & 4 & 9 & February \\
\hline Lokoja & 3 & - & - & - & - & 2 & 5 & March \\
\hline- & - & - & - & - & - & 1 & 1 & April \\
\hline Zariagi & - & - & - & - & 4 & - & 4 & May \\
\hline $\begin{array}{l}\text { Natako-Zariagi } \\
\text { Felele }\end{array}$ & 6 & - & - & - & 2 & 3 & 11 & June \\
\hline Kabba Junction & - & - & - & - & 4 & 2 & 6 & July \\
\hline $\begin{array}{l}\text { Lokoja(Salem } \\
\text { University) }\end{array}$ & 12 & - & 3 & - & - & 4 & 19 & August \\
\hline Zariagi & - & - & - & - & 7 & 5 & 12 & September \\
\hline & - & - & - & - & 3 & 1 & 4 & October \\
\hline Zariagi & 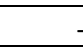 & - & 1 & - & 1 & 6 & 8 & November \\
\hline Kabba Junction & 2 & - & - & - & 15 & 2 & 19 & December \\
\hline Total(\%) & 28 & & 4 & & 36 & 31 & 101 & \\
\hline
\end{tabular}

The accident conditions of children involved in road traffic crash at different routes in Lokoja as shown in Table 8 varies from minor to severe. Many of the children reportedly died in road traffic crashes. More than $60 \%$ of accidents occurred along the federal or major roads, particularly along Lokoja- Kabba route and Lokoja- Abuja route in the city.

Table 8: Reported Cases of Children Involved in Road Traffic Crashes at Federal Medical Centre Lokoja, Lokoja, Kogi State

\begin{tabular}{|c|c|c|c|c|c|c|c|}
\hline File & Sex & Age & Accident Location & $\begin{array}{l}\text { Part Involved in } \\
\text { bruises }\end{array}$ & $\begin{array}{l}\text { Condition of } \\
\text { patient }\end{array}$ & $\begin{array}{l}\text { Days in } \\
\text { Hospital }\end{array}$ & Survival \\
\hline $\begin{array}{l}790564 \\
28 / 11 / 15\end{array}$ & $M$ & 15 & NTA Roundabout Lokoja & $\begin{array}{l}\text { Facial braises on } \\
\text { motorcycle }\end{array}$ & $\begin{array}{l}\text { Minor } \\
\text { accident on } \\
\text { motorcycle }\end{array}$ & 3 days & $\begin{array}{l}\text { Survive and } \\
\text { discharged }\end{array}$ \\
\hline $\begin{array}{l}790429 \\
13 / 12 / 15\end{array}$ & $M$ & 16 & $\begin{array}{l}\text { Head on collision of two } \\
\text { buses at Kabba junction }\end{array}$ & Humerus facture & $\begin{array}{l}\text { Severe } \\
\text { accident } \\
\text { brought in un- } \\
\text { conscious }\end{array}$ & 1 month & Later referred \\
\hline $\begin{array}{l}790422 \\
18 / 12 / 15\end{array}$ & $\mathrm{~F}$ & 17 & $\begin{array}{l}\text { Head on collision of two } \\
\text { buses Kabba Junction }\end{array}$ & $\begin{array}{l}\text { Right upper limb } \\
\text { fracture }\end{array}$ & $\begin{array}{l}\text { Severe } \\
\text { accident }\end{array}$ & 2 months & $\begin{array}{l}\text { Survival } \\
\text { discharge follow- } \\
\text { up }\end{array}$ \\
\hline $\begin{array}{l}790565 \\
5 / 11 / 15\end{array}$ & $M$ & 13 & $\begin{array}{l}\text { Truck and car Peugeot } \\
\text { collision at Felele Lokoja }\end{array}$ & $\begin{array}{l}\text { Upper Lip and } \\
\text { shoulder laceration }\end{array}$ & $\begin{array}{l}\text { Severe } \\
\text { accident }\end{array}$ & 17 days & Discharge \\
\hline $\begin{array}{l}790563 \\
5 / 11 / 15\end{array}$ & $M$ & 13 & $\begin{array}{l}\text { Frontal scalp avulsion } \\
\text { and clip dislocation } \\
\text { Ajaokuta Lokoja Road }\end{array}$ & $\begin{array}{l}\text { Frontal scalp } \\
\text { avulsion and Hip } \\
\text { dislocation }\end{array}$ & $\begin{array}{l}\text { Brought in } \\
\text { unconscious }\end{array}$ & 1 month & $\begin{array}{l}\text { Referred } \\
\text { conscious }\end{array}$ \\
\hline $\begin{array}{l}790575 \\
3 / 1 / 16\end{array}$ & M & 6 & - & $\begin{array}{l}\text { Avlusion of right Hip } \\
\text { \& Tendom } \\
\text { involvement }\end{array}$ & $\begin{array}{l}\text { Not Severe } \\
\text { Conscious }\end{array}$ & 2 hours & $\begin{array}{l}\text { Discharged for } \\
\text { outpatient } \\
\text { treatment }\end{array}$ \\
\hline $\begin{array}{l}790979 \\
8 / 2 / 16\end{array}$ & $M$ & 14 & Lokoja - Abuja Road & Pelvic fracture & $\begin{array}{l}\text { Severe } \\
\text { unconscious }\end{array}$ & 6 hours & $\begin{array}{l}\text { Referred to the } \\
\text { university of } \\
\text { Abuja Teaching } \\
\text { Hospital }\end{array}$ \\
\hline $\begin{array}{l}791235 \\
16 / 2 / 16\end{array}$ & $\mathrm{~F}$ & 5 & NTA Roundabout Lokoja & $\begin{array}{l}\text { Facial bruises on } \\
\text { both arms }\end{array}$ & $\begin{array}{l}\text { Minor } \\
\text { accident }\end{array}$ & 4 hours & $\begin{array}{l}\text { Discharged as } \\
\text { outpatient }\end{array}$ \\
\hline $\begin{array}{l}791293 \\
18 / 3 / 16\end{array}$ & $\mathrm{~F}$ & $2 \frac{1}{2}$ & Ajaokuta - Lokoja Road & $\begin{array}{l}\text { Motorcycle Bilateral } \\
\text { per orbital swelling }\end{array}$ & $\begin{array}{l}\text { On } \\
\text { motorcycle }\end{array}$ & 7 days & Discharged later \\
\hline $\begin{array}{l}872781 \\
6 / 9 / 16\end{array}$ & $\mathrm{~F}$ & $\begin{array}{l}1 \text { year } \\
4 \\
\text { months }\end{array}$ & Ganaja Junction & $\begin{array}{l}\text { Motorcycle Right- } \\
\text { hand fraction }\end{array}$ & Severe & 3 months & $\begin{array}{l}\text { Discharged as } \\
\text { orthopaedic } \\
\text { case }\end{array}$ \\
\hline $\begin{array}{l}872944 \\
6 / 9 / 16\end{array}$ & $\mathrm{~F}$ & 7 & Kabawa Area Lokoja & $\begin{array}{l}\text { Bleeding from } \\
\text { mouth }\end{array}$ & $\begin{array}{l}\text { Minor } \\
\text { accident on } \\
\text { motorcycle }\end{array}$ & 3 hours & Discharged \\
\hline 7907891 & $M$ & 12 & Abuja-Lokoja & Head Injury & Unconscious & 6 days & Died \\
\hline $\begin{array}{l}7907992 \\
2 / 3 / 6\end{array}$ & $\mathrm{~F}$ & 13 & Koto- Karffe road & $\begin{array}{l}\text { Oral bleeding Head } \\
\text { on collision of two } \\
\text { buses }\end{array}$ & Minor & 1 day & Discharged \\
\hline
\end{tabular}




\begin{tabular}{|l|l|l|l|l|l|l|l|}
\hline $\begin{array}{l}797192 \\
27 / 3 / 16\end{array}$ & M & 15 & Ajaokuta - Lokoja Road & $\begin{array}{l}\text { Collision of bus and } \\
\text { Motorcycle } \\
\text { bleeding from Nose } \\
\text { and Ear }\end{array}$ & $\begin{array}{l}\text { Severe } \\
\text { accident }\end{array}$ & 7 days & $\begin{array}{l}\text { Discharged and } \\
\text { referred }\end{array}$ \\
\hline
\end{tabular}

Source: Unpublished Cases of Children Involved in Road Traffic Crashes extracted from Archive of Accident and Emergency Sections at Federal Medical Centre Lokoja

\section{Conclusion and Planning Implications}

The study examined the characteristics of automobile trip to school in Lokoja, an emerging city in north central Nigeria. At the introductory part of the study, the paper discussed the trend of automobile demand in Nigeria and the pattern of children traffic crashes as a result of high demand for automobile trip to school. The methodological section utilised both primary and secondary data to elicit information on the mode preference of children to school in Lokoja. Also, data relating to road traffic crashes of children were obtained from archive sources. Descriptive and inferential statistics were used to analyse the data. Several issues were highlighted. One is that the town planners did not envisage the population explosion of the city in years ahead. But as the years went by, the population almost quadrupled at an alarming rate, making it very difficult for a new plan to be formulated. With this increase came also the increase of automobiles, tricycles, motorcycles, etc. Thus road crash was a resultant effect. Evidence from the literature showed how developed economies like USA, Italy and Austria etc managed their population increase, especially as it concern students trip to school. The results of the research reveal that more than $70 \%$ of children rely on automobile (tricycle, motorcycle, school bus and car) for their school trips. The resultant effects of this are high traffic crashes by children on both intra and inter-city

\section{References}

Adeoye, N. O. (2012). Spatio-temporal analysis of land use/cover change of Lokoja-a confluence town. Journal of Geography and Geology, 4(4), 40 -51. https://doi.org/10.5539/jgg.v4n4p40

Adetunji, M. A., \& Aloba, O. (2018). Analysis of the Distribution Pattern and Accessibility of Students to Secondary Educational Facilities in Lokoja, Kogi State, Nigeria. Journal of Analele Universităţii din Oradea-Seria Geografie, 28(1), 113-124. http://geografieuoradea.ro/Reviste/Anale/Art/20181/11.AUOG_762_Musilimu.pdf

Adeyinka, A. M. (2017). Assessment of Traffic Delay on Selected Route Segments in Lokoja, Kogi State, Nigeria Canadian Journal of Tropical Geography (CJTG), 4(1), 1-10. https://www3.laurentian.ca/rcgtcjtg/volume-4-issue-1/assessment-of-traffic-delay- roads in the Lokoja metropolis. Many children involved in road traffic crashes in the last few years have sustained minor and serious injuries, while many have lost their lives in the course of their trips to school in the city. The study made far reaching recommendations. First, the study recommends the need to encourage the use of school buses in Lokoja and similar other cities in Nigeria to minimise a large number of vehicular movement on roads as this may likely reduce casualties among school children as a result of road traffic crashes. This recommendation could be backed by legislation. Similarly, the study also recommends that there is a need to improve road transport infrastructure through the provision of pedestrian walkways to encourage children to engage in active walking to schools rather than relying on automobile trips to schools. And finally, security operatives who have been furnished with different routes that students use to school be tasked to ensure that safety measures are adhered to strictly, curb crashes in this emerging city, Lokoja in North Central Nigeria.

\section{Acknowledgement}

This research did not receive any grant from any funding agencies.

\section{Conflict of interests}

The author declares no conflict of interest.

on-selected-route-segments-in-lokoja-kogi-statenigeria/?lang=en

Badri, M. A. (2013). School travel modes: factors influencing parental choice in Abu Dhabi. International Journal of Education Economics and Development, 4(3), 203-218. https:/dx.doi.org/10.1504/IJEED.2013.056010

Baker, J., Basu, R., Cropper, M., Lall, S., \& Takeuchi, A. (2005). Urban poverty and transport: the case of Mumbai (Vol. 3693). World Bank Publications. https://doi.org/10.1596/1813-9450-3693

Centres for Disease Control and Prevention. Physical Activity and the Health of Young People. https://www.who.int/dietphysicalactivity/factsheet _young_people/en/

Collins, D. C. A., \& Kearns, R. A. (2001). The safe journeys of an enterprising school: negotiating landscapes of opportunity and risk. Health \& Place, 7(4), 293- 
306. https:/doi.org/10.1016/S1353-8292(01)000211

Department for Transport. (2014). National Travel Survey: 2013.

https:/www.gov.uk/government/statistics/nationaltravel-survey-2013

Easton, S., \& Ferrari, E. (2015). Children's travel to schoolthe interaction of individual, neighbourhood and school factors. Transport Policy, 44, 9-18. https:/doi.org/10.1016/j.tranpol.2015.05.023

Federal Medical Centre. (2017). Unpublished Cases of Children Involved in Road Traffic Crashes extracted from Achieve of Accident and Emergency Sections at Federal Medical Centre Lokoja.

Federal Road Safety Corps (2017). Creating a Safe Motoring Environment in Nigeria. https://frsc.gov.ng/wpcontent/uploads/2018/09/AnnualReport2017.pdf

Goeverden, C. D. v., \& Boer, E. d. (2013). School travel behaviour in the Netherlands and Flanders. Transport Policy, 26, 73-84. https:/doi.org/10.1016/j.tranpol.2013.01.004

Ipingbemi, O., \& Aiworo, A. B. (2013). Journey to school, safety and security of school children in Benin City, Nigeria. Transportation Research Part F: Traffic Psychology and Behaviour, 19, 77-84. https:/doi.org/10.1016/j.trf.2013.03.004

Kim, C. (2014). The journey to school: A case study at Mission Hill School Tufts University]. http://sites.tufts.edu/MaryDavis/files/2014/04/TheJourney-to-School-Christina-Kim.pdf

Kopnina, H., \& Williams, M. (2012). Car attitudes in children from different socio-economic backgrounds in the Netherlands. Transport Policy, 24, 118-125. https:/doi.org/10.1016/j.tranpol.2012.07.010

National Population, C. (2007). Federal Republic of Nigeria official gazette.

National Bureau of Statistics. (2017). Nigeria's vehicle population data reveals towering opportunities. https://nairametrics.com/2017/12/11/vehiclepopulation-in-nigeria-is-11547236-nbs-data/

Ogunsanya, A. A. (2004). Perspectives of Urban Transportation in Nigeria (Nigeria Institute of Transport Technology Issue.

Olawepo, R. A. (2009). Evaluating Housing Problems through Participatory Rural Appraisal in Lokoja Nigeria. African research review, 3(1), 77-96 https://doi.org/10.4314/afrrev.v3i1.43557

Olawole, M. O. (2016). Mode choice of undergraduates: A case study of lecture trips in Nigeria. The Indonesian Journal of Geography, 48(1), 145-156. https://doi.org/10.22146/ijg.17630
The Car Crash Detective. (2018). SCHOOL BUSES SAFER THAN DRIVING / WALKING YOUR CHILD TO SCHOOL.

https://www.thecarcrashdetective.com/schoolbuses-safer-than-driving-walking-child-school/

Timperio, A., Ball, K., Salmon, J., Roberts, R., Giles-Corti, B., Simmons, D., Baur, L. A., \& Crawford, D. (2006). Personal, Family, Social, and Environmental Correlates of Active Commuting to School. American Journal of Preventive Medicine, $30(1)$ 45-51. https:/doi.org/10.1016/j.amepre.2005.08.047

World Health, O. (2015). Global status report on road safety 2015. World Health Organization.

Check for

How to Cite this Article:

Adetunji, M. A. (2020). Automobile Trips to School and Safety Perspectives of Unplanned Lokoja Metropolis in North Central Nigeria. Journal of Contemporary Urban Affairs, 4(1), 61-70. https://doi.org/10.25034/ijcua.2020.v4n1-6 